\title{
$17: 36057629-36037508$
}

National Cancer Institute

\section{Source}

National Cancer Institute. 17: 36057629-36037508. NCI Thesaurus. Code C45039.

Physical location of SMARCE1_Gene 